\title{
Riolan's muscle: action and indications for botulinum toxin injection
}

\begin{abstract}
Purpose To study the effect of injecting botulinum toxin into the region of Riolan's muscle in three conditions, namely the typical form of essential blepharospasm, the palpebral form of essential blepharospasm and hemifacial spasm.

Method Six patients with the typical form of essential blepharospasm and 4 patients with the palpebral form of essential blepharospasm, all of whom had previously been treated with conventional bilateral periorbital injections, were treated with injections of the toxin into the region of Riolan's muscle at the medial and lateral extremities of the upper lids. Thirty patients with hemifacial spasm, all of whom had previously been treated with conventional periorbital injections, were treated with injections of the toxin into the region of Riolan's muscle at the medial and lateral extremities of the upper lid on the affected side.
\end{abstract}

Results Five of 6 patients with typical essential blepharospasm preferred the Riolan's injections and one had no preference. All of the four patients with the palpebral form of essential blepharospasm preferred the Riolan's injections. They, previously, had hardly been able to open their eyes. Twentysix of the patients with hemifacial spasm preferred the Riolan's injections; the other 4 decided to continue with periorbital injections. The amount of toxin used in this new method of treatment is considerably less than that used in conventional methods for these diseases.

Conclusion Riolan's injections of botulinum toxin are the preferred modality of treatment for all types of blepharospasm and cost considerably less.

Key words Apraxia of lid opening, Blepharospasm, Blinking, Hemifacial spasm, Palpebral form of blepharospasm, Ptosis, Riolan's muscle
This study demonstrates that the muscle of Riolan plays the major part in the closure of the lids and probably initiates the sphincter type of closure effected by the orbital portion of orbicularis. Furthermore, it postulates that there is a delicate balance between the resting tones of the upper lid Riolan's muscle and the levator palpebrae superioris which determines the position of the upper lid at rest. The lid can be elevated, at rest, by injections of botulinum toxin into Riolan's muscle and if an excessive dose of the toxin is given the patient will be unable to shut the eye. These factors have important implications in the management of various types of ptosis.

Illustrated here (Fig. 1) is a new light microscopic preparation of a sagittal section of the lower part of an upper lid. It shows Riolan's muscle lying in the posterior half of the lid margin at its extreme edge.

Jean Riolan the Younger (1580-1657) was a French physician and anatomist. William Harvey, in his Exercitato anatomica de motu cordis et sanguinis in animalibus, described him as 'that prince of anatomists'. Riolan subsequently made a fierce attack on Harvey's work. In the Fifth Book of 'A Sure Guide or The Best and Nearest Way to Physick and Chyrurgery, written in Latine by Johannes Riolanus and Englished by Nic. Culpeper (printed by Peter Cole at his shop, at the Sign of the Printing-Press in Cornhill near the Royal Exchange, 1657)', there is a paragraph in the misplaced page 228 which reads 'The Skin of the Eye-Browes and of the whole face being industriously dissected, there appears a double orbicular muscle which does circularly cover the socket of the Eye a Fingersbreadth on al sides and is spred under each Eyelid. Also you shall find the Musculus Ciliaris, stretched out orbicularly under the Tarsus'. In the left-hand margin beside this paragraph appear the headings 'The Orbicularis' and, lower down, 'The Ciliaris', clearly differentiating the two muscles. This was probably the first description of the ciliary bundle.

The Centenary Edition of Gray's Anatomy $(1958)^{1}$ describes a ciliary bundle of the orbicularis oculi, but does not mention the name
I.A. Mackie

Eye Department

St George's Hospital London SW17 OQT, UK

Mr I.A. Mackie, FRCS,

FRCOphth

99 Harley Street

London W1N 1DF, UK

Received: 8 September 1999 Accepted in revised form: 19 January 2000 


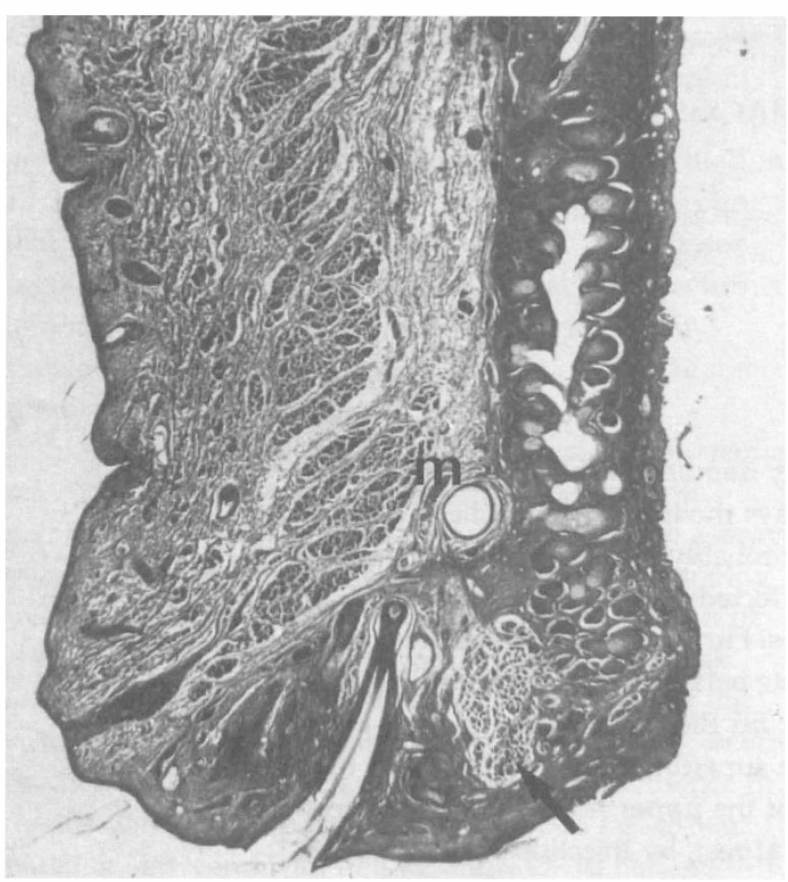

Fig. 1. Light microscopic preparation of a sagittal section of the lower part of an upper lid. Riolan's muscle is shown in the lower right-hand corner and indicated by an arrow. (Illustration kindly supplied by Professor Gordon Ruskell.)

Riolan. This is true of all previous editions going back to 1858 and editions up to the present. Figure 1036 in this Centenary Edition shows a bundle of muscle in the posterior half of the upper lid margin quite separate from the fibres of the palpebral portion of orbicularis. A new figure (8.459) in the most recent 38th edition (1995), ${ }^{2}$ provided by Professor Gordon Ruskell, shows this ciliary bundle behind the lashes in the posterior half of the lid margin. Again there is no mention of the name Riolan.

The first volume of the Handbuch des Gesammten Augenheilkunde by A. Graefe and T. Saemish (1874) ${ }^{3}$ contains a section on the microscopic anatomy of the lids (pp. 60-87). A picture of a microscopic section of an upper lid shows the ciliary bundle of the orbicularis muscle in the posterior one-third of the lid margin but no mention is made of the name Riolan. This belies the suggestion, which has been made to the author, that the name crept into the English literature from Continental usage.

The textbook The Anatomy of the Human Orbit and Accessory Organs of Vision by S.E. Whitnall (1921) ${ }^{4}$ states 'there is a further division of the orbicularis which calls for mention; this is a small fasciculus of extremely thin fibres, amongst the finest, indeed of the whole body, which runs close along the free margin of each lid, separated off from the rest of the muscle by and lying behind the follicles of the eyelashes; it is known as the marginal part of orbicularis (pars marginalis or pars ciliaris) or ciliary bundle of Riolan, and a few of its fibres, seen in microscopical section to lie behind the openings of the ducts of the tarsal glands, are called the "subtarsal portion". The fibres of the muscle nearest the palpebral border (pars ciliaris) have the important function of keeping the lid edges in close approximation of the

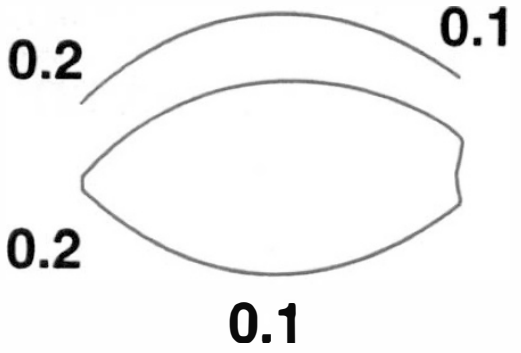

Fig. 2. Pattern of the usual periorbital injections of botulinum toxin in essential blepharospasm and hemifacial spasm. The superior curve in the diagram represents the superior orbital ridge. The figures represent the quantities, in millilitres, of a solution of 500 units of Dysport in 2.5 ml of normal saline.

globe, so contracting the mouth of the conjunctival sac and preventing the entrance of foreign bodies; these fibres, from their close relation to the terminal portion of the tarsal glands, may be concerned with the secretion of the latter and those overlying the bulbs of the cilia may, by their pressure in contraction, determine the curve of the outgrowing eyelashes.'

Figure 52 of the 1st edition of The Anatomy of the Eye and Orbit by Eugene Wolff $(1933)^{5}$ is a vertical section of the upper lid. It shows what is labelled Riolan's muscle to be quite small and lying in front of, and behind, the openings of the meibomian glands in the posterior half of the lid margin. This figure continues in all the editions including the current 8th edition. In Figure 189 of the 4th edition $(1954)^{6}$ the muscle is seen to be continuous nasally with Horner's muscle.

The most recent edition of Wolff's Anatomy of the Eye and Orbit by Bron, Tripathi and Tripathi (1998) ${ }^{7}$ describes the muscle of Riolan as 'filling almost the whole thickness of the lid margin' and 'traversed by ciliary follicles, glands of Moll and excretory ducts of tarsal glands'. This edition states that the palpebral part of the orbicularis muscle closes the lids gently, as in blinking. The orbital part of the orbicularis muscle is said to close the lids firmly and draw the skin of the forehead, temple and cheek medially. When both orbital and palpebral parts contract the eyelids are said to be "screwed up".' It is stated that the palpebral part of orbicularis is opposed by the levator palpebrae superioris.

Typical essential blepharospasm is a bilateral disease in which the eyes are almost always 'screwed up' either episodically or permanently. Botulinum toxin A, by injection, is used as a treatment. It is usually injected into the orbital portions of orbicularis, to destroy neuromuscular junctions and thus put the muscle out of action or at least impair its action. Fig. 2 and its legend detail the sites of conventional injections together with the usual doses used. Viewed histologically, the neuromuscular junctions are re-established in about 6 weeks by a process known as nerve sprouting.

Rarely, cases are seen in which the eyes are closed and cannot be opened, but are not screwed up. This picture can be complicated when the eyes cannot be opened but the superior orbital portions of orbicularis are grossly hypertrophied by long-term overaction in an attempt to 


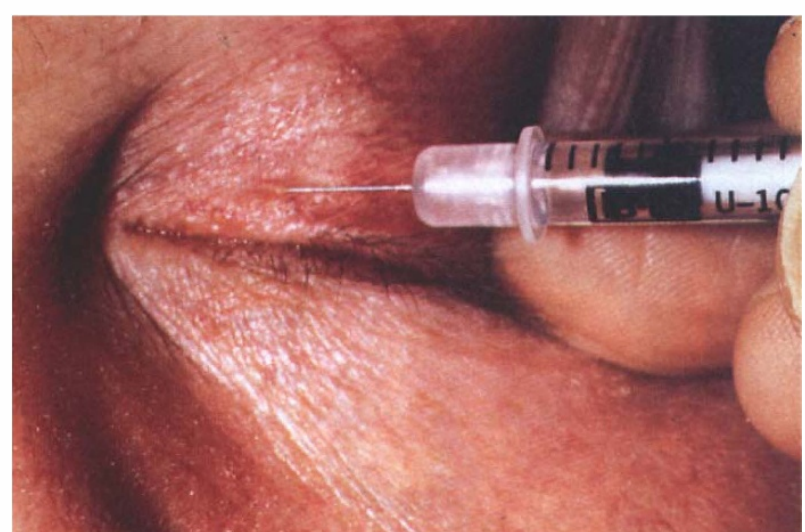

Fig. 3. Injection of Dysport into the region of the lid margin $(2 \mathrm{~mm}$ from its extreme edge). A $0.3 \mathrm{ml}$ diabetic syringe is used in order to make precise dosage possible. The usual dose is $0.02 \mathrm{ml}$ of a solution of 500 units in $2.5 \mathrm{ml}$ normal saline. The range is $0.01-0.07 \mathrm{ml}$. Both medial and lateral extremities of the muscle are injected.

open them. Elston ${ }^{8}$ has drawn attention to this palpebral or pretarsal form of essential blepharospasm involving only the muscles of the lids. In these cases, conventional injections of botulinum toxin into the orbital portions of orbicularis and even into the palpebral portions are, in the author's experience, of little avail. The patient may be thought to have abnormal resistance, or even antibodies, to the toxin. ${ }^{9}$ This condition would appear analogous to what has been referred to as 'apraxia of lid opening' in the neurological literature. It has been studied by Krack and Marion ${ }^{10}$ in a neurological setting. These authors treated their patients with botulinum toxin injections directed towards the junction of the preseptal and pretarsal parts of the palpebral orbicularis oculi. They report that after treatment $83 \%$ of their 29 patients improved on a clinical scale.

Sometimes, in desperation, these resistant patients have been subjected to major surgery. Facial nerve avulsion has been superseded by an orbicularis muscle stripping operation because of the exceedingly high recurrence rate along with many other major complications. The Moorfields Eye Hospital experience of facial nerve avulsion has been documented by Grandas et al. ${ }^{11}$ as has the experience with orbicularis stripping. ${ }^{12}$ In the avulsion procedure there were 27 cases. Recurrences appeared in 22, on average 1 year after surgery. In the orbicularis stripping procedure, again performed at Moorfields Eye Hospital, there were 8 patients. In only 2 cases was some improvement obtained. Two patients had significant benefit, but 1 of these had a recurrence after 4 months. Unwanted side effects were forehead numbness, bilateral ptosis and a bad cosmetic result.

Hemifacial spasm is a much commoner condition than essential blepharospasm. In the author's 9 years' experience at the Botulinum Clinic at St George's Hospital, London, it would appear to be about 5 times commoner. In a large number of cases, especially at the beginning of the disease, it involves solely the orbicularis and these cases might be better termed essential unilateral blepharospasm. It is common knowledge that the condition which is called essential blepharospasm may involve the face and even the platysma muscles as well.

The status of hemifacial spasm as a dystonia has been disputed. Jannetta ${ }^{13}$ believes that it is a 'hyperactive reactive syndrome'. He advocates 'decompressing' the nerve with a neurosurgical sponge at craniotomy. A series of 648 patients so operated have been reported as having excellent results in $84 \%$ and partial success in $7 \%$ 10 years post-operatively. The operation is not without great danger. $^{14}$

The author's interest in Riolan's muscle came about because of one of his patients, aged 48 years, who could not manage to open her eyes. Botulinum toxin injections, which he had given her to the superior and inferior orbital portions of orbicularis, had been completely ineffective. Further injections he gave into the palpebral portions of orbicularis, midway between the fold of the lid and its margin, were slightly effective, resulting in a palpebral aperture of $2 \mathrm{~mm}$ or even less. These injections had to be repeated every 2 weeks and occasionally, due to leakage, presumably through tissue planes, to the levator palpebrae superioris muscle, would result in a tightly shut eye for about 6 weeks. In order to avoid this occurrence, and knowing of the existence of Riolan's muscle, the author injected botulinum toxin into either end of the upper eyelid as near as practical to its margin (Fig. 3). Next day the patient's eyes were wide open and remained so for about 8 weeks. The author then, with informed consent, tried this with other poor responders whom he considered had the palpebral form of essential blepharospasm. The results were so encouraging that he progressed, with informed consent, to patients with essential blepharospasm, who could not be labelled as having the 'palpebral' form, and from there to hemifacial spasm.

The disadvantage of injections to the superior and inferior portions of orbicularis in hemifacial spasm is that most patients develop a drooping of the ipsilateral side of the mouth, which they find very distressing. Friends and acquaintances frequently ask if they have had a stroke. Another feature is cocking (elevation) of the ipsilateral eyebrow. In some cases the face looks grossly asymmetrical at rest. Smiling or laughing grossly emphasises this minor facial palsy (Figs. 4, 5). These features take several months to disappear after the cessation of conventional injections.

\section{Patients and methods}

All the patients, with the exception of 2, were recruited at the Botulinum Clinic at St George's Hospital, London, which is a tertiary referral clinic for all the hospital departments and also for neighbouring hospitals. The author has run this clinic single-handed for the last 9 years. The great majority of the patients had been treated, long term, by the author with conventional periorbital injections. 


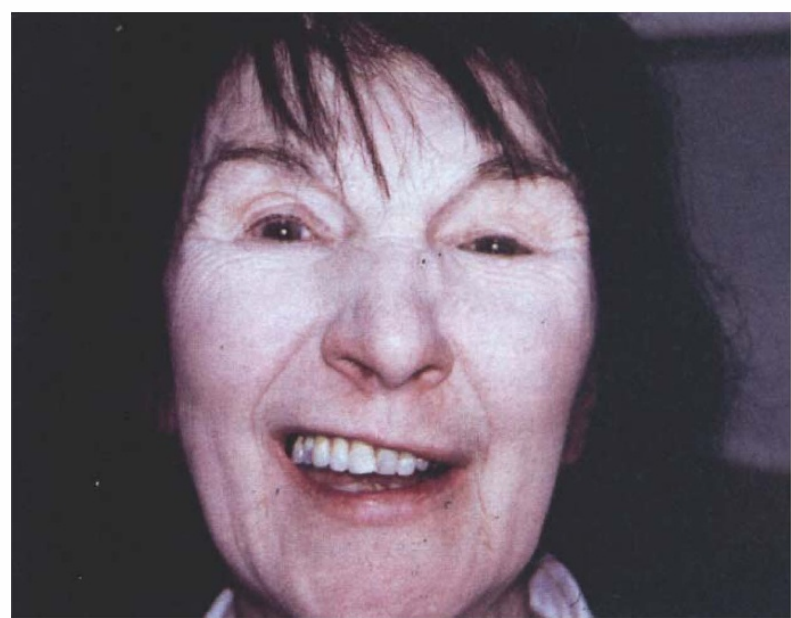

Fig. 4. A patient with drooping of the angle of the mouth on the side of conventional injections of botulinum toxin A for left hemifacial spasm. This is emphasised when she smiles or laughs.

The proposed new procedure was explained to these patients and they were warned that the injections are more painful than those into the periorbital region but that the pain is momentary. Very few declined to proceed. The injections are given with a $0.3 \mathrm{ml}$ combined diabetic syringe and needle (Micro-Fine, Becton

Dickinson) (Fig. 3). This makes it easy to work in doses of diluted toxin (500 units of Dysport in $2.5 \mathrm{ml}$ normal saline) ranging from $0.01 \mathrm{ml}$ to $0.07 \mathrm{ml}$ ( 2 to 14 units). The author's usual starting dose is $0.02 \mathrm{ml}$ (4 units) and this is a common final dose. The effect of the injections lasts for 6-12 weeks. If too much toxin is given the eye will have a staring appearance due to elevation of the upper lid at rest (Fig. 5). With a markedly excessive dose of the toxin (usually in the region of $0.05 \mathrm{ml}$, i.e. 10 units) the eye may not shut properly and there will be constant, excessive tears and the vision will be blurred. This passes off in a week or two and has not proved to be a serious problem. These side effects occurred at the beginning of this study when the value of starting with small doses was not

Table 1. Botulinum toxin injections into Riolan's muscle for essential blepharospasm

\begin{tabular}{|c|c|c|c|c|}
\hline $\begin{array}{l}\text { Case } \\
\text { no. }\end{array}$ & Sex & $\begin{array}{c}\text { Type of } \\
\text { blepharospasm }\end{array}$ & Preference $^{a}$ & Dosage $^{b}$ \\
\hline 1 & $\mathrm{~F}$ & Typical & Preferred & $0.05 \mathrm{ml}$ \\
\hline 2 & $\mathrm{~F}$ & Typical & Preferred & $0.05 \mathrm{ml}$ \\
\hline 3 & M & Typical & No preference & $0.04 \mathrm{ml}$ \\
\hline 4 & $\mathrm{~F}$ & Typical & Preferred & $\begin{array}{l}0.06 \mathrm{ml} \text { plus } 0.05 \mathrm{ml} \\
\times 2 \text { to the superior } \\
\text { orbital portion of the } \\
\text { right orbicularis }\end{array}$ \\
\hline 5 & M & Typical & Preferred & $0.04 \mathrm{ml}$ \\
\hline 6 & M & Typical & Preferred & $\begin{array}{l}0.05 \mathrm{ml} \text { plus } 0.05 \mathrm{ml} \text { to } \\
\text { each nasolabial fold }\end{array}$ \\
\hline 7 & M & Palpebral & Preferred & $0.07 \mathrm{ml}$ \\
\hline 8 & $\mathrm{~F}$ & Palpebral & Preferred & $0.01 \mathrm{ml}$ \\
\hline 9 & $\mathrm{~F}$ & Palpebral & Preferred & $0.05 \mathrm{ml}$ \\
\hline 10 & $\mathrm{~F}$ & Palpebral & Preferred & $0.07 \mathrm{ml}$ \\
\hline
\end{tabular}

${ }^{a}$ Whether Riolan's muscle injections were preferred to conventional injections.

${ }^{b}$ The amount of toxin ultimately required is indicated for each extremity, medial and lateral, of each of the two muscles involved.

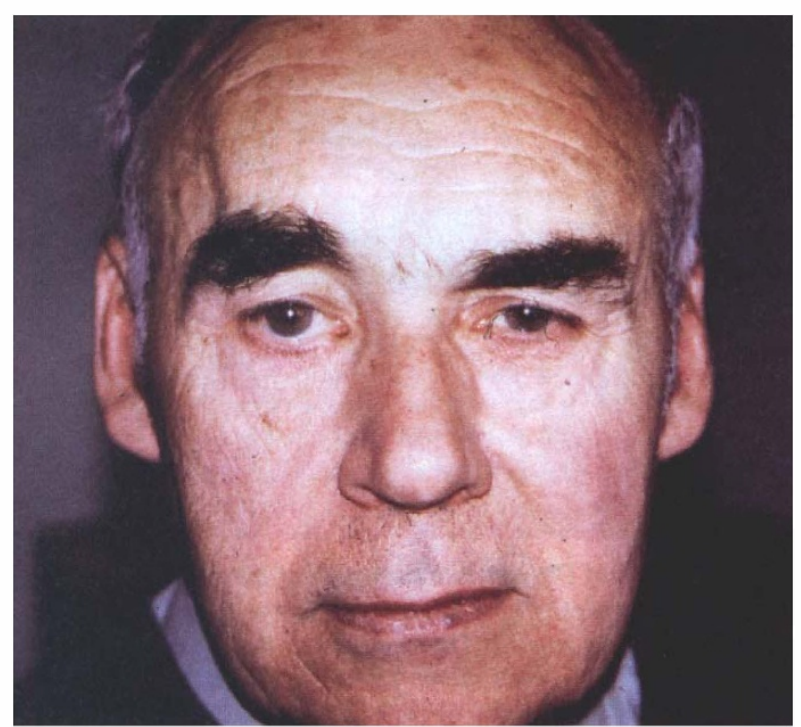

Fig. 5. A patient suffering from right hemifacial spasm and treated by the author for 8 years with conventional injections of botulinum toxin to the orbital portion of orbicularis. Note the mouth droop and the cocked eyebrow on the right-hand side. This photograph was taken 2 weeks after injections of $0.02 \mathrm{ml}$ of the toxin to either side of Riolan's muscle in the right upper lid. The right upper lid is elevated, beyond the level of the left because too much toxin was given. A more appropriate dose would have been $0.01 \mathrm{ml}$ for each injection.

appreciated. The dosage is far more critical than with periorbital injections. Only one of the patients who took part in this study is currently upset by the momentary sharp, nipping pain of the injections, and that is the first patient to be treated. Infiltrating her lids with $2 \%$

lignocaine still results in unbearable pain and it is only when bupivicaine $0.5 \%$ is used to infiltrate the lids that she is rendered pain free. Patients have differing thresholds for pain!

\section{Results}

A total of 40 patients have had lid margin injections. All had previously had injections into the orbicularis muscles. After a period of at least 6 weeks, patients were simply asked if they preferred the lid margin injections to the conventional ones. 'Preferring' implied that they wanted to continue with the lid margin injections.

Of 10 patients with essential blepharospasm of both types, 9 preferred the lid margin injections and 1 had no preference. The latter patient had typical essential blepharospasm (Table 1). Of 30 patients with hemifacial spasm 26 preferred the lid margin injections (Table 2); 4 wished to continue with conventional injections (Table 3).

Over a period of several months, the patients with hemifacial spasm could be seen to have a gradual resolution of the ipsilateral mouth droop and the cocked eyebrow (Figs. 4, 5).

Some patients with hemifacial spasm required a further injection of $0.05 \mathrm{ml}$ to the ipsilateral side of the face, midway between a line drawn between the nostril and the side of the mouth (the nasolabial fold), to control facial spasm. This, in the author's experience, does not result in drooping of the ipsilateral side of the mouth. 
Table 2. Botulinum toxin injections into Riolan's muscle for hemifacial spasm: patients who preferred this type of injection

\begin{tabular}{|c|c|c|c|}
\hline $\begin{array}{c}\text { Case } \\
\text { no. }\end{array}$ & Sex & $\begin{array}{l}\text { Side of } \\
\text { spasm }\end{array}$ & Dosage $^{a}$ \\
\hline 1 & $\mathrm{M}$ & $\mathrm{L}$ & $\begin{array}{l}0.06 \mathrm{ml}(0.06 \mathrm{ml} \text { to middle of lower Riolan } \\
\text { muscle) }\end{array}$ \\
\hline 2 & $\mathrm{~F}$ & $\mathrm{~L}$ & $\begin{array}{l}0.01 \mathrm{ml}(0.05 \mathrm{ml} \text { to contralateral nasolacrimal } \\
\text { fold })\end{array}$ \\
\hline 3 & $\mathrm{~F}$ & $\mathrm{~L}$ & $0.01 \mathrm{ml}$ \\
\hline 4 & $\mathrm{~F}$ & $\mathrm{R}$ & $0.025 \mathrm{ml}$ \\
\hline 5 & $\mathrm{~F}$ & $\mathrm{R}$ & $\begin{array}{l}0.02 \mathrm{ml}(0.05 \mathrm{ml} \text { to ipsilateral nasolacrimal } \\
\text { fold })\end{array}$ \\
\hline 6 & M & $\mathrm{L}$ & $0.01 \mathrm{ml}$ \\
\hline 7 & $\mathrm{~F}$ & $\mathrm{~L}$ & $\begin{array}{l}0.025 \mathrm{ml}(0.05 \mathrm{ml} \text { to ipsilateral nasolacrimal } \\
\text { fold })\end{array}$ \\
\hline 8 & $\mathrm{~F}$ & $\mathrm{~L}$ & $\begin{array}{l}0.02 \mathrm{ml}(0.05 \mathrm{ml} \text { to ipsilateral nasolacrimal } \\
\text { fold })\end{array}$ \\
\hline 9 & $\mathrm{~F}$ & $\mathrm{~L}$ & $0.02 \mathrm{ml}$ \\
\hline 10 & $\mathrm{~F}$ & $\mathrm{~L}$ & $0.02 \mathrm{ml}(0.02 \mathrm{ml}$ to middle of lower lid $)$ \\
\hline 11 & M & $\mathrm{R}$ & $0.03 \mathrm{ml}$ \\
\hline 12 & $\mathrm{~F}$ & $\mathrm{~L}$ & $\begin{array}{l}0.02 \mathrm{ml}(0.05 \mathrm{ml} \text { to ipsilateral nasolacrimal } \\
\text { fold })\end{array}$ \\
\hline 13 & $\mathrm{~F}$ & $\mathrm{R}$ & $0.01 \mathrm{ml}$ \\
\hline 14 & M & $\mathrm{R}$ & $\begin{array}{l}0.02 \mathrm{ml}(0.1 \mathrm{ml} \text { to ipsilateral nasolacrimal } \\
\text { fold })\end{array}$ \\
\hline 15 & M & $\mathrm{L}$ & $0.04 \mathrm{ml}$ \\
\hline 16 & $\mathrm{~F}$ & $\mathrm{R}$ & $0.03 \mathrm{ml}(0.05 \mathrm{ml}$ to middle of lower lid $)$ \\
\hline 17 & $\mathrm{~F}$ & $\mathrm{~L}$ & $0.02 \mathrm{ml}$ \\
\hline 18 & $\mathrm{~F}$ & $\mathrm{R}$ & $\begin{array}{l}0.01 \mathrm{ml}(0.01 \mathrm{ml} \text { to middle of lower Riolan } \\
\text { muscle) }\end{array}$ \\
\hline 19 & $\mathrm{~F}$ & $\mathrm{R}$ & $\begin{array}{l}0.02 \mathrm{ml}(0.02 \mathrm{ml} \text { to middle of lower Riolan } \\
\text { muscle) }\end{array}$ \\
\hline 20 & M & $\mathrm{L}$ & $0.01 \mathrm{ml}$ \\
\hline 21 & $\mathrm{~F}$ & $\mathrm{R}$ & $\begin{array}{l}0.01 \mathrm{ml}(0.1 \mathrm{ml} \text { to middle of lower Riolan } \\
\text { muscle })\end{array}$ \\
\hline 22 & $\mathrm{~F}$ & $\mathrm{R}$ & $0.01 \mathrm{ml}(0.05 \mathrm{ml}$ to homolateral side of face $)$ \\
\hline 23 & M & $\mathrm{L}$ & $\begin{array}{l}0.01 \mathrm{ml} \text { injections }(0.05 \mathrm{ml} \times 2 \text { to ipsilateral } \\
\text { superior orbital orbicularis muscle })\end{array}$ \\
\hline 24 & M & $\mathrm{L}$ & $0.02 \mathrm{ml}$ \\
\hline 25 & M & $\mathrm{L}$ & $0.01 \mathrm{ml}$ \\
\hline 26 & $\mathrm{~F}$ & $\mathrm{R}$ & $0.01 \mathrm{ml}$ \\
\hline
\end{tabular}

${ }^{a}$ The amount of toxin indicated was ultimately required for each extremity, medial and lateral, of the muscle.

Injections were sometimes made into the middle of Riolan's muscle in the middle of the lower lid margin. Although not mentioned in any text book, the author is assured that it exists in this site (Professor Gordon Ruskell, personal communication). These injections would not appear to control spasms in the ipsilateral side of the face but further observation is required to validate this view.

\section{Discussion}

Riolan's muscle would appear to be the main instigator of the blink and closure of the eye. In the normal eye of all races, its tethered portions, laterally and nasally, lie below the centre of the cornea and it is easy to see that it is strategically placed for these actions.

Essential blepharospasm and hemifacial spasm may be triggered by a dystonia of Riolan's muscle or muscles and the alleviation of these diseases by the injection of botulinum toxin into this muscle would give credence to this proposition.
Table 3. Botulinum toxin injections into Riolan's muscle for hemifacial spasm: patients who did not prefer this type of injection

\begin{tabular}{|c|c|c|c|}
\hline $\begin{array}{c}\text { Case } \\
\text { no. }\end{array}$ & Sex & $\begin{array}{l}\text { Side of } \\
\text { spasm }\end{array}$ & Comments \\
\hline 1 & $\mathrm{~F}$ & $\mathrm{R}$ & $\begin{array}{l}\text { The } 0.025 \mathrm{ml} \text { injections were evidently not } \\
\text { sufficient and her eye continued to twitch. } \\
\text { She asked to continue with the standard } \\
\text { injections which she had been having }\end{array}$ \\
\hline 2 & $\mathrm{~F}$ & $\mathrm{R}$ & $\begin{array}{l}\text { The initial injections were of } 0.01 \mathrm{ml} \text { and } \\
\text { perhaps not enough. The eye did not twitch } \\
\text { but she felt that she had to keep holding or } \\
\text { closing it at times. She had no problems with } \\
\text { the previous injections and in particular had } \\
\text { no mouth angle drop }\end{array}$ \\
\hline 3 & $\mathrm{~F}$ & $\mathrm{R}$ & $\begin{array}{l}\text { The initial injections were of } 0.02 \mathrm{ml} \text {. She } \\
\text { objected to the injections and found herself } \\
\text { shuddering after them. She complained that } \\
\text { their effect did not last as long }\end{array}$ \\
\hline 4 & $\mathrm{M}$ & $\mathrm{L}$ & $\begin{array}{l}\text { The initial injections were of } 0.05 \mathrm{ml} \text { and } \\
\text { resulted in double vision, blurred vision and } \\
50 \% \text { ptosis. They were given at the begin- } \\
\text { ning of the author's experience with this } \\
\text { modality of treatment. The ipsilateral side of } \\
\text { his face continued to twitch. He did not wish } \\
\text { to continue }\end{array}$ \\
\hline
\end{tabular}

The implications for this modality of treatment are great. The conventional injections for both essential blepharospasm and hemifacial spasm using Dysport, Botulinum Toxin A (Ipsen) at a dilution of 500 mouse units in $2.5 \mathrm{ml}$ normal saline (beware: the mouse unit of Botox, Botulinum Toxin A (Allergan) is about 5 times stronger) are $0.2 \mathrm{ml}$ (40 units) to the upper and lower temporal areas of the orbital portions of an orbicularis muscle, together with $0.1 \mathrm{ml}$ (20 units) nasally to the superior orbital portion and $0.1 \mathrm{ml}$ (20 units) to the muscle midway along the lower lid (to avoid the inferior oblique) (Fig. 2). These injections, using large amounts of toxin, carry the risk of diplopia, due to involvement of the inferior oblique, and ptosis due to involvement of the superior rectus muscle. Presumably the spread of toxin is along tissue planes.

In financial terms, this is $0.6 \mathrm{ml}$ (120 units) per eye. This is near to $25 \%$ of a bottle of Dysport which contains 500 units and costs in the region of $£ 200.00$. This means an expenditure of $£ 50.00$ per eye. Double this to $£ 100.00$ for essential blepharospasm. These injections have to be repeated about every 6-10 weeks. Lid margin injections into the region of Riolan's muscle are considerably cheaper. The dosages range from $0.01 \mathrm{ml}$ to $0.07 \mathrm{ml}(2$ units to 14 units). A unit of toxin costs about $40 \mathrm{p}$.

In essential blepharospasm the most frequent doses are $0.04 \mathrm{ml}$ and $0.05 \mathrm{ml}$ (8 units and 10 units) at a total cost, for four injections, of $£ 12.80$ or $£ 16.00$. In essential blepharospasm, added nasolabial injections, to control facial spasm, are seldom required with this new method.

In hemifacial spasm the most frequent dose is $0.02 \mathrm{ml}$ (4 units). At a cost of about 40p per unit this makes the most frequent total cost of two injections for hemifacial spasm about $£ 3.20$ (8 units), with an exceptional high of about $£ 9.60$ ( 24 units). Added injections, usually of 
$0.05 \mathrm{ml}$ (10 units) of toxin, may be required for facial spasm in both conventional treatment and that described here and this is indicated in Table 3.

In essential blepharospasm, whether of the orbital or pretarsal (palpebral) type, and in hemifacial spasm, lid margin injections are preferred by the vast majority of patients and cost considerably less.

\section{References}

1. Gray's anatomy, centenary edition. London: Longmans, Green, 1958:1257, fig.1036.

2. Gray's anatomy. New York: Churchill Livingstone, 1995:1362,fig 8.459.

3. Graefe A, Saemish T. Handbuch des gesammten Augenheilkunde. Leipzig: Wilhelm Engelmann, 1874:60-87.

4. Whitnall SE. Anatomy of the human orbit and accessory organs of vision. London: Henry Frowde/Hodder and Stoughton, 1921:129,178-9.

5. Wolff E. The anatomy of the eye and orbit, 1st ed. London: HK Lewis, 1933:88,fig 52.
6. Wolffe E. The anatomy of the eye and orbit, 4 th ed. London: HK Lewis, 1954:200:fig 189.

7. Bron AJ, Tripathi RC, Tripathi BJ. Wolff's anatomy of the eye and orbit. London: Chapman and Hall, 1998:34.

8. Elston JS. A new variant of blepharospasm. J Neurol Neurosurg Psychiatry 1992;55:369-71.

9. Palace J, Nairne A, Hyman N, Doherty TV, Vincent A. A radioimmuno-precipitation assay for antibodies to botulinum A. Neurology 1998;50:1463-6.

10. Krack P, Marion MH. 'Apraxia of lid opening', a focal eyelid dystonia: clinical study of 32 patients. Mov Disord 1994;9:610-5.

11. Grandas F, Elston J, Quinn N, Marsden CD. Blepharospasm: a review of 264 cases. J Neurol Neurosurg Psychiatry 1988;51:767-72.

12. Grandas F, Elston J, Quinn N, Marsden CD. Pharmacologic, surgical and infiltration of botulinum toxin treatment in blepharospasm. Neurologia (Spain) 1989;4:194-9.

13. Jannetta PJ. Neurovascular compression and systemic disease. Ann Surg 1980;192:518-25.

14. Barker FG 2nd, Jannetta PJ, Bissonette DJ, Shields PT, Larkins MV, Jho HD. Neurovascular decompression for hemifacial spasm. J Neurosurg 1995;82:201-10. 